\title{
IMPLEMENTASI KEBIJAKAN PEMANFAATAN PARIWISATA TAMAN NASIONAL BETUNG KERIHUN DAN DANAU SENTARUM (TNBKDS) KALIMANTAN BARAT
}

\section{POLICY IMPLEMENTATION OF TOURISM UTILIZATION AT TAMAN NASIONAL BETUNG KERIHUN DAN DANAU SENTARUM (TNBKDS) WEST KALIMANTAN}

\author{
Sadam Husen $^{1}$, Rita Rahmawati ${ }^{2}$, Denny Hernawan ${ }^{3}$. \\ ${ }^{1}$ Jurusan Ilmu Administrasi Negara Fakultas Ilmu Sosial dan Ilmu Politik Universitas \\ Djuanda, Jl Tol Ciawi No 1, Kotak Pos 35 Bogor 16770. \\ ${ }^{2}$ Jurusan Ilmu Administrasi Negara Fakultas Ilmu Sosial dan Ilmu Politik Universitas \\ Djuanda, Jl Tol Ciawi No 1, Kotak Pos 35 Bogor 16770. \\ ${ }^{3}$ Jurusan Ilmu Administrasi Negara Fakultas Ilmu Sosial dan Ilmu Politik Universitas \\ Djuanda, Jl Tol Ciawi No 1, Kotak Pos 35 Bogor 16770.
}

(Diterima oleh Dewan Redaksi: 01-08-2017)

(Dipublikasikan oleh Dewan Redaksi: 01-10-2017)

\begin{abstract}
Betung Kerihun National Park and Danau Sentarum (TNBKDS) have tourism potential based on the classification of tourist attraction object (ODTW), if developed and utilized optimally will bring socio-economic impacts for the people around the area of TNBKDS. The purpose of this research is to know the implementation of policy of tourism utilization of TNBKDS in relation of socioeconomic impact for society around the area. By using approach of theory of policy implementation model G. Edward III which measure success of policy implementation through 4 variables include; Communication, Resources, Disposition, and Bureaucratic Structure. The method used is descriptive analysis by using quantitative approach. With data analysis techniques using the calculation of Weight Mean Score (WMS). And the analytical unit is divided into 2 sources, namely the implementer of the Central Park TNBKDS based on purposive sampling with the number of samples of 28 employees involved in the field of tourism. And the policy target of the village community Menua Sadap as cultural attractions and the village of Sepandan as a natural tourist attraction TNBKDS with purposive samples each 30 respondents with gender representation, ketokohan, work and so forth. The results of the study are generally based on the assessment of implementing the policy (implementor) is quite good with the acquisition score of 3.33. While the assessment of policy targets based on ODTW classification that is; cultural tourism Menua Sadap obtained a score of 3.49 according to the criteria of interpretation including good category, while the natural attractions Lake Sentarum village Sepandan with a score of 2.60 according to the criteria of interpretation including bad category. Based on the results of the analysis, the difference between the results of the assessment occurs due to communication intensity and bureaucratic structure, and the most fundamental because it is influenced by local culture / culture factors that influence the social, economic and political environment of the policy target itself.
\end{abstract}

Keywords: Implementation of policy, tourism utilization, community of TNBKDS area 


\begin{abstract}
ABSTRAK
Taman Nasional Betung Kerihun Dan Danau Sentarum (TNBKDS) memiliki potensi pariwisata berdasarkan klasifikasi objek daya tarik wisata (ODTW), apabila dikembangkan dan dimanfaatkan secara optimal akan membawa dampak sosial-ekonomi bagi masyarakat sekitar kawasan TNBKDS. Tujuan penelitian ini untuk mengetahui implementasi kebijakan pemanfaatan pariwisata TNBKDS dalam kaitan dampak sosial ekonomi bagi masyarakat sekitar kawasan. Dengan menggunakan pendekatan teori model implementasi kebijakan G. Edward III yang mengukur keberhasilan implementasi kebijakan melalui 4 variabel meliputi; Komunikasi, Sumberdaya, Disposisi, dan Struktur birokrasi. Metode yang digunakan adalah deskriptif analisis dengan menggunakan pendekatan kuantitatif. Dengan teknik analisis data menggunakan perhitungan Weight Mean Score (WMS). Serta Unit analisis yang terbagi 2 sumber yaitu pelaksana kebijakan (implementor) Balai Besar TNBKDS berdasarkan purposive sampling dengan jumlah sampel 28 pegawai yang terlibat dalam bidang pariwisata. Dan sasaran kebijakan yaitu masyarakat desa Menua Sadap sebagai objek wisata budaya dan desa Sepandan sebagai objek wisata alam TNBKDS dengan sampel purposive masing-masing 30 responden dengan keterwakilan gender, ketokohan, pekerjaan dan sebagainya. Hasil penelitian secara umum berdasarkan penilaian pelaksana kebijakan (implementor) cukup baik dengan perolehan skor 3,33. Sedangkan penilaian sasaran kebijakan berdasarkan klasifikasi ODTW yaitu; wisata budaya Menua Sadap diperoleh skor 3,49 menurut kriteria penafsiran termasuk kategori baik, sedangkan wisata alam Danau Sentarum desa Sepandan dengan skor 2,60 menurut kriteria penafsiran termasuk kategori buruk. Berdasarkan hasil analisis, perbedaan hasil penilaian terjadi karena masalah intensitas komunikasi dan struktur birokrasi, serta yang paling mendasar karena dipengaruhi oleh faktor kultur/budaya lokal yang turut mempengaruhi lingkungan sosial, ekonomi dan politik sasaran kebijakan itu sendiri.
\end{abstract}

Keywords: Implementasi kebijakan, pemanfaatan pariwisata, Masyarakat kawasan TNBKDS

Nama Penulis Utama, Tahun. Judul Artikel. Sadam Husen, 2017. Implementasi Kebijakan Pemanfaatan Pariwisata Taman Nasionl Betung Kerihun dan Danau Sentarum (TNBKSD) di Kalimantan Barat, Jurnal Governansi.

\section{PENDAHULUAN}

Pariwisata dewasa ini dipandang sebagai salah satu sektor yang dapat mendorong roda perekonomian suatu daerah. Sebagaimana yang terjadi di daerah Bali. Menurut Baiquini dkk. (dalam Jupir, 2013) menyatakan bahwa "pariwisata berperan signifikan dan telah mampu menjadi penggerak roda perekonomian masyarakat Bali. Sekitar $80 \%$ dari seluruh masyarakat Bali, kehidupannya tergantung pada pariwisata".

Salah satu tempat yang dapat dikembangkan untuk pariwisata adalah taman nasional.
Dengan mengacu pada UndangUndang No. 5 Tahun 1990 tentang Konservasi Sumber Daya Alam Hayati dan Ekosistemnya, pasal 1 ayat 14, diartikan sebagai kawasan pelestarian alam yang mempunyai ekosistem asli, dikelola dengan sistem zonasi yang dimanfaatkan untuk tujuan penelitian, ilmu pengetahuan,

pendidikan, menunjang budidaya, pariwisata dan rekreasi.

Taman Nasional Betung Kerihun dan Danau Sentarum (TNBKDS) dengan luas sekitar \pm 944.086,80 hektar yang terletak di kab. Kapuas Hulu propinsi Kalimantan Barat ditetapkan melalui Keputusan Mentri 
Kehutanan nomor 467/Kpts-II/1995 tertanggal 5 September 1995. Kemudian diperbaharui pada tahun 2014 dengan џuas816.693.40 Ha (SK Menhut No. 3075/Menhut-VII/KUH/ 2014). Dan Danau Sentarum yang ditunjuk pada tahun 1999 dengan luas $\pm 132.000 \mathrm{Ha}$ dan ditetapkan pada tahun 2014 dengan luas \pm 127.393.4 Ha (SK Menhut No. /4815 Menhut-VII/KUH/ 2014, tanggal 30 Juni 2016). Yang dalam pengelolaanya berada di bawah Unit Pelaksana Tugas Taman Nasional yaitu Balai Besar Taman Nasional Betung Kerihun dan Danau Sentarum (BBTNBKDS) berdasarkan SK. Mentri Lingkungan Hidup dan Kehutanan Nomor P.7/Menlhk/Setjen/OTL.0 /1/2016 tentang Organisasi dan Tata Kerja Unit Pelaksana Teknis Taman Nasional.

Taman Nasional Betung Kerihun Dan Danau Sentarum (TNBKDS) tentunya

memiliki keindahan alam dan keanekaragaman hayati dan spesies endemik yang langka yang dapat dikembangkan menjadi objek daya tarik wisata (ODTW) yang memiliki potensi pariwisata yang besar dan unggul apabila dikembangkan dan dikelola secara optimal dapat dijadikan objek daya tarik wisata (ODTW) andalan di Kabupaten Kapuas Hulu, serta didukung pula oleh kondisi sosial budaya masyarakat kabupaten Kapuas Hulu yang memiliki beragam masyarakat adat dari berbagai jenis etnik Dayak seperti Dayak Iban salah satunya yang masih memegang kultur/budaya dan tradisi serta kearifan lokal masyarakat adat Dayak. Dengan begitu diharapkan masyarakat dapat merasakan keadilan dan manfaat dari kebijakan penetapan kawasan Betung Kerihun dan Danau Sentarum sebagai taman nasional.

Dengan demikian penelitian ini menjadi penting untuk mengetahui implementasi kebijakan pemanfaatan pariwisata Taman Nasional Betung Kerihun dan Danau Sentarum (TNBKDS) dimana masih banyak masyarakat yang memanfaatkan sumberdaya dikawasan

Taman nasional sebagai sumber penghidupan, sehingga diharapkan dengan pemanfaatan pariwisata Taman Nasional Betung Kerihun Dan Danau Sentarum (TNBKDS) dapat dijadikan solusi alternatif bagi masyarakat sekitar kawasan TNBKDS, di samping itu di Kab. Kapuas Hulu masih terdapat masyarakat miskin yaitu sekitar 23,740 jiwa (Bps Kab. Kapuas Hulu 2016).

Melalui pemanfaatan pariwisata Taman Nasional Betung Kerihun Dan Danau Sentarum (TNBKDS) diharapkan hal itu dapat meningkatkan pendapatan masyarakat, menunjang pembangunan daerah serta kesejahteraan masyarakat di Kabupaten Kapuas Hulu.

\section{MATERI DAN METODE}

Implementasi merupakan salah satu proses dalam suatu kebijakan. Kebijakan tidak akan berguna/ berjalan apabila proses implementasi tidak dilaksanakan. Sehingga proses implementasi menjadi bagian penting dalam suatu kebijakan. Termasuk dalam implementasi kebijakan penetapan Taman Nasional.

Taman Nasional ditetapkan atas dasar kajian teknis ekologis dan sosial budaya masyarakat yang tinggal di sektar kawasan dengan menjamin keberlanjutan kehidupannya. Namun demikian keberlanjutan ekologis cenderung lebih diutamakan ketimbang sosial masyarakat. Dengan alasan menjaga keberlanjutan ekologis, masyarkat lokal kehilangan akses terhadap sumberdaya hutan yang mereka manfaatkan sebagai sumber penghidupan

bagi keberlanjutan kehidupannya. Sehingga terjadilah konflik kepentingan dalam kawasan taman nasional.

Masyarakat sekitar kawasan memanfaatkan hutan sebagai sumberdaya penghidupannya, sedangkan pengelola kawasan taman 
nasional (pemerintah) memanfaatkan hutan sebagai tempat pelestarian sumberdaya hutan dan ekosistem yang terdapat di dalammnya. Sebagaimana yang terjadi di Taman Nasional Gunung Halimun Salak (TNGHS). Konflik terjadi karena adanya overlaping tata kelola hutan menurut kelembagaan lokal (masyarakat) dan kelembagaan negara (Rahmawati, 2013).

Pemerintah berupaya meredakan konflik yaitu dengan melibatkan masyarakat lokal delam mengelola dan memanfaatkan bersama kawasan taman nasional. Salah satu pengelolaan dan pemanfaatan bersama kawasan taman nasional adalah pemanfaatan pariwisata kawasan taman nasional.

\section{Populasi dan Sampel}

Populasi dalam penelitian ini, peneliti menggunakan dua sumber populasi yaitu, populasi dari pegawai yang berjumlah 82 orang di Balai Besar Taman Nasional Betung Kerihun dan Danau Sentarum (BBTNBKDS) selaku pelaksana kebijakan (implementor) dan perwakilan dari masyarakat lokal yang tinggal disekitar kawasan Taman Nasional Betung Kerihun dan Danau Sentarum (TNBKDS) yang dibatasi menjadi 2 (dua) desa yaitu desa Manua Sadap dan desa Sepandan selaku sasaran kebijakan.

Penarikan sampel menggunakan teknik purposive sampling dengan pertimbangan sampel harus berasal dari pelaksana kebijakan dan sasaran kebijakan. Yaitu untuk pelaksana kebijakan ditarik sampel 28 orang pegawai yang berkaitan dengan pemanfaatan pariwisata dan untuk sasaran kebijakan ditarik sampel 60 orang dari masyarakat desa Menua Sadap sebagai wisata budaya dan masyarakat desa Sepandan sebagai wisata alam Danau Sentarum dengan keterwakilan gender, ketokohan, pekerjaan dan sebagainya.

\section{Teknik Pengumpulan Data}

Teknik pengumpulan data dalam penelitian ini menggunakan:

1) Studi Kepustakaan/literatur yang merupakan pengumpulan data dan informasi yang relevan dengan cara mengkaji literatur dari pengelola kawasan taman nasional, dinas terkait dan lembaga kemasyarakat yang bergerak dikepariwisataan Kapuas Hulu;

2) Studi Lapangan yang merupakan pengumpulan data dan informasi dengan cara pengamatan langsung dilapangan. Peneliti mengamati

langsung bagaimana proses implementasi dilaksanakan baik oleh pelaksana kebijakan maupun oleh sasaran kebijakan (masyarakat lokal) yakni masyarakat desa Menua Sadap yang memanfaatkan budaya lokal sebagai pariwisata dan masyarakat desa Sepandan yang memanfaatkan Danau Sentarum sebagai pariwisata alam.

\section{Wawancara}

merupakan pengumpulan data dan informasi yang relevan dengan cara mengajukan pertanyaan yang telah ditentukan peneliti, pertanyaan langsung melalui proses tanya jawab kepada responden yang dianggap mengetahui terkait masalah penelitian in

4) Kuesioner

merupakan penegumpulan data dan informasi melalui cara pengajuan pertanyaan terlulis kepada responden yang telah ditentukan.

\section{Teknis Analisis Data}

Teknik analisis data dalam penelitian ini dengan menggunakan rumus Weight Mean Score (WMS) berikut ini. 


$$
\mathrm{M}=\sum \mathrm{fx} / \mathrm{n}
$$

\section{Keterangan :}

M =Perolehan angka kriteria penafsiran $\mathrm{f}=$ Frekuensi jawaban

$\mathrm{x}=$ Pembobotan (skala nilai)

$\sum=$ Penjumlahan

$\mathrm{n}=$ jumlah seluruh jawaban responden

Sedangkan untuk skala pengukuran dalam penelitian ini menggunakan skala likert. Dengan Kriteria penafsiran di bawah ini:

\begin{tabular}{ll}
\multicolumn{2}{c}{ Tabel Skala likert } \\
\hline Skor & Kriteria \\
\hline $4,21-5,00$ & Sangat Baik \\
$3,41-4,20$ & Baik \\
$2,61-3,40$ & Sedang \\
$1,81-2,60$ & Buruk \\
$1,00-1,80$ & Sangat Buruk \\
\hline
\end{tabular}

Sumber: Bakri Siregar, 1993

\section{HASIL DAN PEMBAHASAN}

\section{Gambaran Lokus Penelitian}

\section{Balai Besar Taman Nasional Betung Kerihun Dan Danau Sentarum (BBTNBKDS)}

Balai Besar Taman Nasional Betung Kerihun dan Danau Sentarum (BBTNBKDS) merupakan Unit Pelaksana Teknis (UPT) dari Direktorat Jenderal Konservasi Sumber Daya Alam dan Ekosistem (Ditjen KSDAE) yang terbentuk berdasarkan Peraturan Menteri Lingkungan Hidup dan Kehutanan Republik Indonesia

No. P.7/Menlhk/Setjen/OTL.0/1/2016 tentang Organisasi dan Tata Kerja Unit Pelaksana Teknis Taman Nasional (Lampiran Peraturan Menteri Lingkungan Hidup dan Kehutanan Republik Indonesia)

BBTNBKDS ditetapkan sebagai unit pengelola penyelenggaraan konservasi sumberdaya alam dan ekosistemnya yang berada di bawah dan bertanggung jawab kepada Direktur Jenderal Konservasi
Sumber Daya Alam dan Ekosistem menjadi UPT Teknis Taman Nasional Kelas I, Balai Besar Taman Nasional Tipe A dengan jabatan Kepala Balai Besar adalah jabatan struktural Eselon II.b.

Balai Besar Taman Nasional Betung Kerihun dan Danau Sentarum (BBTNBKDS) merupakan organisasi baru hasil penggabungan 2 (dua) UPT, yaitu Balai Besar Taman Nasional Betung Kerihun dan Balai Taman Nasional Danau Sentarum. Sejak diterbitkannya Peraturan Menteri Lingkungan Hidup dan Kehutanan tersebut di atas, nomenklatur organisasi menjadi Balai Besar Taman Nasional Betung Kerihun dan Danau Sentarum yang berkedudukan di Putussibau, Kalimantan Barat. Dengan tugas yang dimiliki yakni penyelenggaraan konservasi sumberdaya alam hayati dan ekosistemnya dan pengelolaan kawasan taman nasional berdasarkan perundang-undangan.

\section{Spesifikasi Pengelolaan Taman Nasional}

Taman Nasional Betung Kerihun (TNBK) Taman Nasional Betung Kerihun (TNBK) adalah kawasan konservasi terbesar di Propinsi Kalimantan Barat yang terletak di Kabupaten Kapuas Hulu. Secara administratif termasuk dalam wilayah empat (4) kecamatan yaitu Kecamatan Putussibau Utara, Kecamatan Putussibau Selatan, Kecamatan Embaloh Hulu, dan Kecamatan Batang Lupar. Secara geografis TNBK terletak diantara koordinat 112010' 47" BT - 1036' 35" LU dan 114012' 49 BT" 0036' 26" LU.

Kawasan TNBK memiliki total area 816.693,40 hektar atau sekitar 27,37\% dari luas total Kabupaten Kapuas Hulu yang terbagi dalam beberapa zonasi. Penetapan zonasi dalam pengelolaan taman nasional didasarkan pada aturan yang dituangkan dalam Peraturan Menteri kehutanan nomor P.56/Menhut II/2006 tentang Pedoman Zonasi Taman Nasional. 
Zonasi merupakan dasar dari pengembangan dan pengelolaan taman nasional dimana zona taman nasional adalah wilayah di dalam taman nasional yang dibedakan menurut fungsi, kepentingan kelola dan kondisi ekologis, sosial, ekonomi, dan budaya masyarakat.

Zonasi Taman Nasional Betung Kerihun telah disahkan melalui Surat Keputusan Dirjen PHKA Nomor : SK.120/IV-KK/2009 tanggal 15 Juli 2009, dan dibuat berdasarkan berbagai aspek kajian meliputi : fisik (iklim, tanah, topografi dan hidrologi), biotik (flora dan fauna) tutupan lahan, sosial ekonomi dan budaya serta aspek legal (RTRW/TGHK). Dari kajian aspek tersebut di atas, diperoleh enam zona TNBK yaitu, zona inti, zona rimba, zona pemanfaatan, zona tradisional, zona religi, budaya dan sejarah, serta zona khusus/pemukiman.

\section{Taman Nasional Danau Sentarum (TNDS)}

Taman Nasional Danau Sentarum (TNDS) adalah kawasan konservasi lahan basah terbesar di Indonesia seluas 127.393,40 hektar yang terletak di hulu Sungai Kapuas, sekitar 700 km dari kota Pontianak Kabupaten Kapuas Hulu, Propinsi Kalimantan Barat. Secara administratif termasuk dalam wilayah 7 (tujuh) kecamatan yaitu Kecamatan Badau, Kecamatan Nanga Kantuk, Kecamatan Batang Lupar, Kecamatan Suhaid,

Kecamatan Selimbau, Kecamatan Jongkong, dan Kecamatan Bunut, 12 Desa dan 45 Dusun/Kampung.

Sebagai salah satu Taman Nasional, TNDS dibagi ke dalam 7 (tujuh) penataan zonasi kawasan TNDS. Penataan zonasi dalam Taman Nasional merupakan mandat negara kepada unit pengelola teknis (UPT) yang dinyatakan dalam Undang-undang Nomor 5 Tahun 1990 tentang Konservasi Sumber Daya Alam Hayati dan Ekosistemnya. Penetapan zonasi dalam pengelolaan taman nasional didasarkan pada aturan yang dituangkan dalam Peraturan Menteri Lingkungan Hidup dan Kehutanan No. P.76/Menlhk/Setjen/2015 tentang Kriteria Zona Pengelolaan Taman Nasional dan Blok Pengelolaan Cagar Alam, Suaka Margasatwa, Taman Hutan Raya dan Taman Wisata Alam. Zonasi merupakan dasar pengembangan dan pengelolaan taman nasional dimana zona taman nasional adalah wilayah atau ruang

yang dibedakan menurut fungsi, kepentingan kelola, kondisi ekologis, sosial, ekonomi, dan budaya masyarakat.

Zonasi Taman Nasional Danau Sentarum telah disahkan melalui Surat Keputusan Dirjen PHKA No. : SK.240/IV-Set/2014 tanggal 20 Nopember 2014, Berdasarkan keputusan tersebut, ditetapkan 7 (tujuh) zona TNDS yaitu, zona inti, zona rimba, zona pemanfaatan, zona tradisional daratan, zona tradisional perairan, rehabilitasi dan zona khusus.

\section{Desa Sepandan}

Secara Geografis Desa Sepandan Kecamatan Batang Lupar Kabupaten Kapuas Hulu terletak pada 1120 22' 94.61" E BT dan 10 03' 61,77" LU dengan Luas Wilayah : 23.751,56 ha. Desa Sepandan berbatasan dengan dengan desa Sungai Abau sebelah utara; sebelah selatan dengan desa Melembam, desa Leboyan kecamatan Selimbau, dan desa Lubuk Pengail kecamatan Suhaid; sebelah timur desa Lanjak Deras dan desa Sungai Ajung; sebelah barat desa Setulang dan Desa Sungai Senunuk.

Desa Sepandan memiliki Jumlah penduduk Desa Sepandan pada tahun 2009 sebanyak 292 KK dan 1.087 jiwa, terdiri dari 547 jiwa laki -Iaki dan 540 jiwa

perempuan. Tingkat pertumbuhan penduduk rata-rata sebesar $1.02 \%$ dalam lima tahun terakhir. Tingkat kepadatan penduduk, di Desa Sepandan rata-rata sebesar 22 jiwa per KM2.

Desa Sepandan adalah desa yang 
berada di ibu kota kecamatan, masyarakatnya sebagian besar bekerja dalam bidang pertanian dan nelayan, sedangkan yang lainnya adalah wiraswasta, jasa dan lain- lain. Desa Sepandan mempunyai beberapa potensi unggulan yang bisa dikembangkan sebagaimanaa berikut :

- Usaha pertanian berupa padi, jagung, singkong, dan pisang;

- Usaha perkebunan berupa karet, sahang (lada), gaharu dan buahbuahan;

- Usaha perikanan berupa penangkapan dan pemeliharaan (kolam dan keramba);

- Usaha kerajinan berupa tenunan, anyaman dan pandai besi;

- Usaha perdagangan;

- Usaha Agrowisata (sebagian besar wilayah desa sepandan penyangga TNDS).

\section{HASIL}

Dengan mengacu pada teori George Edward III yang mengajukan 4 (empat) dimensi yang berperan penting dalam pencapaian keberhasilan implementasi, 4 (empat) dimensi yang dimaksud yang mempengaruhi keberhasilan atau kegagalan implementasi kebijakan yaitu dimensi komunikasi, sumberdaya, disposisi, dan struktur birokrasi. (Widodo, 2011:96).

Dan berikut di bawah ini adalah hasil dan analisis data terkait 4 (empat) dimensi tersebut yang digunakan dalam penelitian ini melalui penyebaran kuesioner kepada pegawai Balai Besar Taman Nasional Betung Kerihun Dan Danau Sentarum (BBTNBKDS) dengan jumlah responden 28 orang serta masyarakat yang tinggal dikawasan sekitar Taman Nasional Betung Dan Danau Senatrum (TNBKDS) yang dibagi ke dalam 2 (dua) kelompok masyarakat yaitu; masyarakat desa Menua Sadap kecamatan Embaloh
Hulu dengan jumlah responden 30 orang dan masyarakat desa Sepandan kec. Batang Lupar yang berjumlah 30 orang.

\section{Dimensi Komunikasi}

Agar implementasi berjalan dengan efektif, sehingga menjadi kunci keberhasilan suatu kebijakan, maka pelaku kebijakan harus memperhatikan dan memahami dimensi komunikasi dalam pengimplementasian kebijakan. Sehingga pelaku kebijakan memahami apa yang menjadi arah dan tujuan dari kebijakan tersebut. Terkhusus dalam implementasi kebijakan pemanfaatan pariwisata Taman Nasional Betung Kerihun Dan Danau Sentarum (TNBKDS), karena hal itu berdampak langsung terhadap kehidupan sosial ekonomi masyarakat sekitar kawasan TNBKDS. Indikator keberhasilan dimensi komunikasi dapat dilihat dari 3 (tiga) indikator diantaranya:

1) Proses penyampain informasi;

2) Kejelasan informasi;

3) Konsistensiinformasiyang disampaikan.

Demikian apabila ketiga indikator tersebut terpenuhi dengan baik oleh pelaku kebijakan, maka dapat dikatakan bahwa komunikasi internal maupun eksternal dalam suatu kebijakan berhasil.

Adapun hasil dari penilaian dimensi komunikasi dalam implementasi kebijakan pemanfaatan pariwisata Taman Nasional Betung Kerihun Dan Danau Sentarum

(TNBKDS) berdasarkan penelitian lapangan diketahui bahwa penilaian terkait dimensi komunikasi pada pemanfaatan pariwisata berdasarkan penilaian kinerja pelaksana kebijakan bahwa dalam Implementasi Kebijakan Pemanfaatan Pariwisata Taman Nasional Betung 
Kerihun Dan Danau Sentarum (BBTNBKDS) terkait dimensi komunikasi diperoleh skor penilaian 3,65 dengan kriteria penafsiran termasuk dalam kategori baik, artinya proses komunikasi internal maupun eksternal sudah dilaksanakan dengan jelas, konsisten dan dapat dipahami.

Hal ini didukung oleh hasil wawancara dengan Kepala Balai Besar Taman Nasional Betung Kerihun Dan Danau Sentarum (BBTNBKDS) dan pengamatan langsung peneliti dilapangan bahwa komunikasi internal maupun eksternal terkait Kebijakan Pemanfaatan Pariwisata TNBKDS sudah dilaksanakan dengan baik melalui rapat internal, sosiasilasi dengan masyarakat dan mitra (LSM) serta berkoordinasi dan bekerja sama dengan Dinas Pariwisata dan Olahraga Kab. Kapuas Hulu. Terkhusus dalam acara festival Danau Sentarum Dan Betung Kerihun yang dilaksanakan sekitar 1 tahun sekali, komunikasi semakin intensif dilaksanakan melalui pamflet, spanduk dan iklan serta sosialisasi kepada

masyarakat dan pihak yang berkepentingan (mitra).

Sedangkan hasil analisis data terkait dimensi komunikasi berdasarkan penilaian sasaran kebijakan yakni pada pemanfaatan pariwisata budaya di desa Menua Sadap diperoleh skor 3,88 dengan kriteria penafsiran termasuk dalam kategori baik, artinya bahwa komunikasi sudah dilaksanakan dengan jelas dan konsisten dan diterima dengan baik oleh masyarakat desa Menua Sadap. Hal ini dipengaruhi oleh faktor kultur/budaya masyarakat Menua Sadap, yang memiliki adat istiadat dayak iban yang dikenal sebagai masyarakat yang masih kuat memegang adat, tradisi dan budayanya, hal ini tercermin dari rumah betang/panjang sebagai tempat tinggalnya. disamping faktor kultur/budaya, faktor kedekatan juga ikut mempengaruhi dalam komunikasi.
Faktor kedekatan menjadi berpengaruh dalam proses komunikasi, dimana pada desa Menua Sadap terdapat Kantor Bidang PTN Wilayah 1 Mataso dan Resort Sadap yang berada satu kompleks dengan rumah betang Dusun Sadap yang menjadi objek pariwisata budaya Menua Sadap. Sehingga implementor dapat melakukan komunikasi dengan masyarakat dengan intersitas yang rutin, sehingga komunikasi pada pemanfaatan pariwisata budaya di desa Menua Sadap menjadi optimal.

Sementara hasil penilaian responden dalam pemanfaatan pariwisata alam di desa Sepandan diperoleh skor 2,65 yang mana menurut kriteria penafsiran termasuk dalam katergori sedang, artinya komunikasi yang diterima oleh masyarakat desa Sepandan belum jelas dan belum konsisten serta belum dipahami dengan baik. Hal ini karena implementor belum melaksanakan komunikasi dengan optimal.

\section{Dimensi Sumberdaya}

Sumberdaya memiliki peranan penting dalam implementasi kebijakan. Sumberdaya yang dimaksud adalah segala sumber yang dapat digunakan untuk mendukung keberhasilan implementasi kebijakan. Sumberdaya ini mencakup sumberdaya manusia yeng mencakup Jumlah pegawai yang memadai; pegawai secara kompetensi, Informasi yang dibutuhkan guna pengambilan keputusan, Anggaran dana, Wewenang/tanggung jawab, dan Fasilitas yang dibutuhkan dalam melaksanakan tugas.

Adapun hasil penilaian pelaksana kebijakan terkait dimensi sumberdaya diperoleh skor penilaian 3,13 yang menurut kriteria penafsiran termasuk dalam kategori sedang, dalam artian sudah cukup memadai.

Secara umum sumberdaya untuk menunjang kegiatan dan program

BBTNBKDS termasuk dalam Implementasi Kebijakan Pemanfaatan 
Pariwisata TNBKDS sudah cukup memadai hal ini sesuai dengan hasil laporan kinerja BBTNBKDS tahun 2016 yang menyatakan bahwa secara umum sumberdaya untuk menunjang pelaksanaan kegiatan cukup memadai. Meskipun belum optimal dalam fungsi dan penggunaannya karena keterbatasan jumlah pegawai.

Sedangkan hasil penilaian masyarakat kawasan TNBKDS yakni masyarakat desa Menua Sadap dan masyarakat desa Sepandan terhadap dimensi sumberdaya diketahui bahwa rekapitulasi jawaban responden masyarakat desa Menua Sadap diperoleh skor 4.18 yang mana menurut kriteria penafsiran termasuk dalam kategori baik. Artinya dalam penilaian masyarakat desa Menua Sadap dalam Implementasi Kebijakan Pemanfaatan Pariwisata budaya TNBKDS terkait dimensi sumberdaya BBTNBKDS memiliki sumberdaya yang memadai.

Namun dalam penilaian masyarakat desa Sepandan diperoleh skor 2,58 yang menurut kriteria penafsiran termasuk dalam kategori buruk, artinya dalam penilaian masyarakat desa Sepandan BBTNBKDS terkait sumberdaya tidak memadai dalam Implementasi Pemanfaatan Pariwisata alam desa Sepandan.

\section{Disposisi (Sikap Pelaksana Kebijakan)}

Sikap dari pelaksana kebijakan akan sangat berpengaruh dalam implementasi kebijakan. Apabila pelaksana kebijakan memiliki sikap yang baik maka implementor akan dapat menjalankan kebijakan dengan baik seperti apa yang diinginkan oleh pembuat kebijakan sebaliknya apabila sikapnya tidak mendukung maka implementasi tidak akan terlaksana dengan baik. Adapun sikap pelaksana kebijakan dapat dilihat dari beberapa indikator diantaranya; Komitmen dalam pelaksanaan tugas; Pemimpin yang tegas; Terjalin hubungan yang baik antar pelaku kebijakan dan Terjalin hubungan baik pelaku dan sasaran kebijakan.

Dan berikut di bawah ini hasil penilaian pelaksana kebijakan terkait dimensi disposisi (sikap pelaksana kebijakan) dalam implementasi kebijakan pariwisata TNBKDS diperoleh skor penilaian 4,59 yang menurut kriteria penafsiran termasuk dalam kategori sangat baik. Artinya pelaksana kebijakan memiliki komitmen yang sangat baik dan sangat mampu menjalin hubungan yang harmonis baik itu antar pelaksana kebijakan maupun dengan sasaran

kebijakan. Berdasarkan pengamatan langsung peneliti dilapangan, dimana pelaksana kebijakan memiliki sikap yang baik dalam artian mampu bekerja secara profesional dalam Implementasi kebijakan Pemanfaatan Pariwisata.

Sedangkan penilaian masyarakat kawasan TNBKDS yakni masyarakat desa Menua Sadap diperoleh skor penilaian 3,45 yang menurut kriteria penafsiran termasuk dalam kategori baik, artinya pelaksana kebijakan telah memiliki komitmen yang baik dan mampu menjalin hubungan yang harmonis dengan masyarakat desa Menua Sadap. Adapun penilaian masyarakat desa Sepandan diperoleh skor 2,75 berada dalam kategori sedang, dalam artian pelaksana kebijakan sudah cukup mampu menjalin hubungan yang harmonis dan memiliki komitmen yang baik

\section{Dimensi Struktur Birokrasi}

Dimensi yang terakhir yang tak kalah penting adalah dimensi Struktur birokrasi memiliki pengaruh yang signifikan terhadap implementasi kebijakan. Struktur birokrasi ini meliputi dua hal yaitu; mekanisme dan struktur birokrasi itu sendiri. Aspek pertama adalah mekanisme, dalam implementasi kebijakan biasanya sudah dibuat Standar Operasional Prosedur (SOP). SOP menjadi pedoman bagi setiap implementor dalam bertindak agar dalam pelaksanaan kebijakan tidak menyimpang dari tujuan dan sasaran 
kebijakan. kedua adalah struktur birokrasi dalam artian tata aliran kerja, struktur birokrasi yang terlalu panjang akan cenderung melemahkan pengawasan dan menyebabkan prosedur birokrasi menjadi rumit (Widodo, 2011).

Dari pernyataan di atas, terdapat 2 (dua) indikator penting dalam struktur birokrasi yang dapat mempengaruhi implementasi kebijakan, termasuk dalam Implementasi Kebijakan Pemanfaatan pariwisata Taman Nasional Betung Kerihun Dan Danau Sentarum (TNBKDS), 2 indikator yang dimaksud diantaranya (1) Standar Operasional Prosedur (SOP); (2) Mengatur tata aliran kerja birokrasi.

Adapun hasil analisis terkait dimensi struktur birokrasi berdasarkan penilaian kinerja pelaksana kebijakan diperoleh skor penilaian 3,26 yang mana menurut kriteria penafsiran termasuk dalam kategori sedang, artinya bahwa mekanisme/SOP dan tata aliran kerja dalam Implementasi Kebijakan Pemanfaatan Pariwisata TNBKDS sudah cukup sesuai dan cukup mudah.

Sedangkan hasil penilaian pada masyarakat desa Menua Sadap sebagai wisata budaya diperoleh skor 3,33 yang dalam kriteria penafsiran termasuk dalam kategori sedang, artinya struktur birokrasi dalam kaitan SOP dan tata aliran kerja TNBKDS sudah cukup sesuai.

Hal ini karena dalam Implementasi Kebijakan Pemanfaatan Pariwisata TNBKDS terkhusus wisata budaya di

Menua Sadap dijalankan melalui Kelompok Pengelola Pariwisata (KPP) Menua Sadap yang berkoordinasi dengan Bidang Pengelolaan Taman Nasional Wilayah I Mataso yang terletak di desa Menua Sadap.

Adapun hasil penilaian masyarakat desa Sepandan diperoleh skor 2,44 yang menurut kriteria penafsiran termasuk dalam kategori buruk. Artinya BBTNBKDS dalam struktur birokrasi belum mampu menjalankannya dengan bail. Hal ini karena dalam Implementasi
Kebijakan Pemanfaatan Pariwisata TNBKDS terkhusus wisata alam di desa Sepandan belum dijalankan melalui Kelompok Pengelola Pariwisata (KPP) seperti di desa Menua Sadap.

\section{PEMBAHASAN}

\section{Implementasi Kebijakan Pariwisata TNBKDS}

Secara umum Implementasi

Kebijakan Pemanfaatan Pariwisata TNBKDS yang terbagi dalam 2 (dua) klasifikasi wisata budaya dan wisata alam, dapat diketahui melalui analisis data hasil rekapitulasi jawaban responden pegawai BBTNBKDS (implementor) terhadap Implementasi Kebijakan Pemanfaatan Pariwisata TNBKDS.

Adapun hasil rekapitulasi diperoleh skor penilaian 3,33 yang munurut kriteria penafsiran termasuk dalam kategori sedang. Dalam artian Balai Besar Taman Nasional Betung Kerihun Dan Danau Sentarum (BBTNBKDS) sudah cukup optimal dalam pengelolaanya. Hanya dari ketersedian SDM dari segi jumlah dan kompetensi masih kurang memadai dalam Implementasi Kebijakan Pemanfaatan Pariwista TNBKDS.

Hal ini didukung dengan survey terkait dampak sosial ekonomi pariwisata bagi masyarakat lokal. Berikut adalah hasil survey yang peneliti lakukan yang disajikan dalam bentuk diagram.

\section{Survey presepsi Pegawai BBTNBKDS terkait Dampak Sosial Ekonomi pariwisata Bagi Masyarakat lokal}

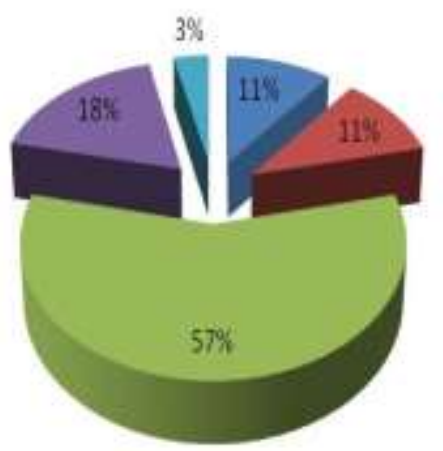

- Sangat Sesua

* Sesuai

incukupSesuai

- Tidak Sesuai

: Sangat Tidak Sesuail 
Sumber: Hasil Penelitian, 2017

Dari data survey presepsi pegawai terkait dampak sosial ekonomi pariwisata bagi masyarakat lokal, dapat diketahui bahwa $57 \%$ atau 16 orang dari 28 responden pegawai BBTNBKDS dalam penelitian ini memberi jawaban cukup sesuai dampak sosial ekonomi pariwisata bagi masyarakat lokal yang tinggal disekitar kawasan TNBKDS. Sedangkan hanya $3 \%$ atau 1 orang memberikan jawaban sangat tidak sesuai. Dengan kata lain hasil survey ini menjadi salah satu indikator bahwa Implementasi Kebijakan Pemanfaatan Pariwisata Taman Nasional Betung Kerihun Dan Danau Sentarum (TNBKDS) sudah cukup optimal.

$\begin{array}{rlr}\text { Namun } & \text { Secara } & \text { spesifikasi } \\ \text { pemanfaatan } & \text { pariwisata } & \text { Taman }\end{array}$
Nasional Betung Kerihun Dan Danau Sentarum (TNBKDS) terbagi ke dalam 2 (dua) klasifikasi pariwisata berdasarkan objek daya tarik wisata (ODTW) yaitu; pariwisata budaya dan pariwisata alam.

Pemanfaatn budaya masyarakat lokal untuk pariwisata di kawasan Taman Nasional Taman Nasional Betung Kerihun Dan Danau Sentarum (TNBKDS) berkembang dari kehidupan masyarakat lokal yang telah dulu dan lama tinggal sebelum ditetapkan sebagai Taman Nasional. Masyarakat lokal yang tinggal sekitar kawasan TNBKDS didominasi tujuh etnis Dayak yang bermukim di sekitar TNBK, yaitu Dayak Iban, Tamambaloh, Taman Sibau, Kantu', Kayaan, Bukat, Dayak Punan dan melayu di kawasan Taman Nasional Danau Sentarum (TNDS).

Sedangkan pemanfaatan pariwisata alam kawasan Taman Nasional Betung Kerihun Dan Danau Sentarum terfokus pada pemanfaatan kawasan Danau Sentarum yang memiliki pesona keindahan alam yang menawan yang telah menjadi Target Rencana Induk Pembangunan Kepariwisataan Nasional (RIPPARNAS) dan menjadi bagian 15 Danau Prioritas Indonesia.

\section{Pemanfaatan Budaya Masyarakat Lokal Untuk Pariwisata TNBKDS}

Kehidupan masyarakat lokal sekitar kawasan TNBKDS yang tetap berpegang pada budaya, adat istiadat dan tradisi menjadi objek daya tarik wisata (ODTW) bagi wisatawan yang apabila di kelola dengan baik, hal itu dapat berdampak pada peningkatan perekonomian masyarakat lokal yang selama ini bergantung pada sumberdaya yang terkandung dalam kawasan TNBKDS.

Berdasarkan hasil rekapitulasi jawaban responden masyarakat desa Menua Sadap terhadap Implementasi Kebijakan Pemanfaatan Pariwisata Taman Nasional Betung Kerihun Dan Danau Sentarum (TNBKDS) spesifikasi wisata budaya menunjukan skor akhir penilaian 3,49 dengan kriteria penafsiran termasuk dalam kategori Baik.

Dalam artian Balai Besar Taman Nasional Betung Kerihun Dan Danau Sentarum (BBTNBKDS) sudah menjalankan secara optimal dalam Implementasi Kebijakan Pemanfaatan Pariwista TNBKDS. Hal ini didukung dengan adanya Kelompok Pegelola Pariwisata (KPP) desa Menua Sadap dan adanya survey dampak sosial ekonomi pariwisata bagi masyarakat Menua Sadap serta analisis data kunjungan wisatawan.

Dalam Pemanfaatan budaya masyarakat lokal, pariwisata TNBKDS di desa Menua Sadap telah dibentuk pengelola pariwisata berbasis masyarakat lokal (community based tourism) dengan nama Kelompok Pengelola Pariwisata Iban Kanyau (KPP Iban Kanyau) terbentuk pada 
tahun 2014. KPP Iban Kanyau dibentuk guna memaksimalkan potensi wisata dengan cara melakukan inventarisasi potensi wisata di desa Menua Sadap dan mengatur pengelolaan kepariwisataan desa Menua Sadap. Berikut ini adalah kepengurusan KPP Iban Kanyau desa Manua Sadap.

\section{Kepengurusan organisasi KPP Iban} Kanyau

\begin{tabular}{|c|c|c|}
\hline \multicolumn{2}{|c|}{ Ketua Umum } & Silvester Jua \\
\hline \multicolumn{2}{|c|}{ Sekretaris Umum } & Saprianus Kaso \\
\hline \multicolumn{2}{|c|}{ Bendahara Umum } & Floresius Itan \\
\hline \multicolumn{3}{|c|}{ Koordinator Tingkat Dusun } \\
\hline \multirow[t]{4}{*}{ A } & \multicolumn{2}{|c|}{ Koordinator Dusun Sadap } \\
\hline & Ketua & Hilarius Jumadi \\
\hline & Sekretaris & Adrianus Gindi \\
\hline & Bendahara & Oktavia Serina \\
\hline \multirow[t]{4}{*}{ B } & \multicolumn{2}{|c|}{ Koordinator Dusun Kelayam } \\
\hline & Ketua & Novi Irwandi Lagi \\
\hline & Sekretaris & Monika Elvi \\
\hline & Bendahara & Yanuarius Lasa \\
\hline \multirow[t]{4}{*}{$\mathbf{C}$} & Koordinator Di & Kerangan Bunut \\
\hline & Ketua & Jesika Jawai \\
\hline & Sekretaris & Titin \\
\hline & Bendahara & Hendrikus Judan \\
\hline
\end{tabular}

Dengan terbentuknya KPP Iban Kanyau di desa Menua Sadap hal itu menjadi suatu indikator bahwa apabila pariwisata dikembangkan dengan baik hal itu akan berdampak positif bagi perekonomian masyarakat dan membuka peluang usaha masyarakat, sebagaimana survey berikut ini.

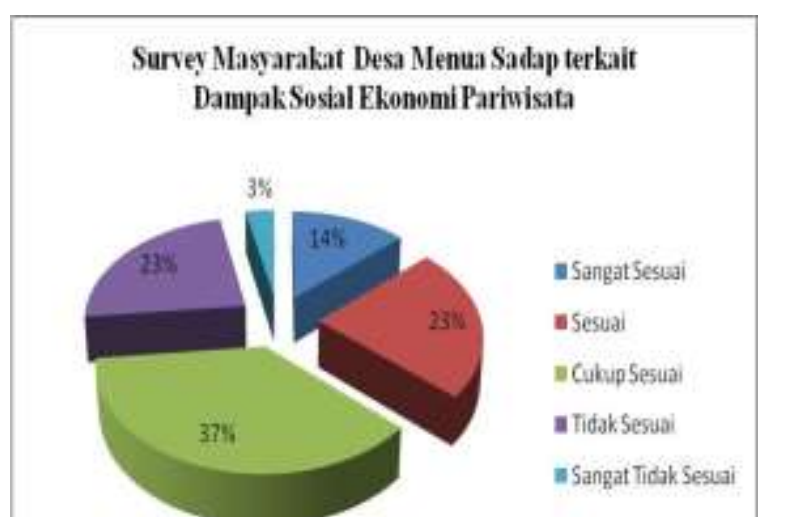

Implementasi Kebijakan Pemanfaatan Pariwisata TNBKDS

Sumber: Hasil Penelitian, 2017

Dari data survey masyarakat desa Menua Sadap terkait dampak sosialekonomi pariwisata, dapat diketahui bahwa $37 \%$ atau 16 orang dari 30 responden Masyarakat desa Menua Sadap dalam penelitian ini menyatakan bahwa, pariwisata memberikan dampak sosial ekonomi yang cukup sesuai bagi masyarakat desa. Sedangkan hanya 3\% atau 1 orang memberikan jawaban sangat tidak sesuai.

Dengan kata lain hasil survey ini menjadi salah satu indikator bahwa Implementasi Kebijakan Pemanfaatan Pariwisata TNBKDS dalam pemanfaatan wisata budaya di desa Menua Sadap sudah optimal dalam penyelenggaraannya.

Adapun dari data kunjungan wisatawan yang berkunjung pada wisata budaya masyarakat Menua Sadap per tahun 2011 sampai 2016 dapat dicermati dalam tabel data berikut ini.

\section{Data Jumlah Kunjungan Wisatawan} 2011-2016

\begin{tabular}{|c|c|c|}
\hline No. & $\begin{array}{l}\text { Tahun } \\
\text { Kunjungan }\end{array}$ & Jumlah Wisatawan \\
\hline 1 & 2011 & 51 Orang \\
\hline 2 & 2012 & 51 Orang \\
\hline 3 & 2013 & 52 Orang \\
\hline 4 & 2014 & 64 Orang \\
\hline 5 & 2015 & 51 Orang \\
\hline 6 & 2016 & 80 Orang \\
\hline
\end{tabular}

Sumber: Dokumen Laporan Kompakh, 2016

Dari data jumlah pengunjung wisatawan diketahui bahwa dalam 6 
(enam) tahun terakhir menunjukan adanya peningkatan jumlah pengunjung pada tahun 2013 dan 2014 sebanyak 12 orang, dan terjadi penurunan pada tahun 2015 sebanyak 13 orang namun terjadi peningkatan di tahun 2016 sebanyak 29 orang pengunjung. Hal ini menunjukan bahwa Kelompok Pengelola Pariwisata (KPP) Iban Kanyau telah melakukan usaha dalam meningkatkan destinasi wisata di desa Menua Sadap.

Berdasarkan hasil wawancara bersama ketua KPP Iban Kanyau diketahui bahwa selama ini dalam penyelenggaran pariwisata di desa Menua Sadap, BBTNBKDS melalui Kepala Resort Sadap telah melakukan pendampingan kepada masyarakat desa Menua Sadap dalam pengelolaannya. Termasuk dalam penyusunan aturan main (lihat dalam lampiran) berkunjung ke masyarakat desa Menua Sadap.

\section{Pemanfaatan Pariwisata Alam TNBKDS}

Berdasarkan hasil rekapitulasi jawaban responden masyarakat desa Sepandan terhadap Implementasi Kebijakan Pemanfaatan Pariwisata Taman Nasional Betung Kerihun Dan Danau Sentarum (TNBKDS) spesifikasi wisata alam menunjukan skor akhir penilaian 2,60 dengan kriteria penafsiran termasuk dalam kategori buruk. Dalam artian Balai Besar Taman Nasional Betung Kerihun Dan Danau Sentarum (BBTNBKDS) belum menjalankan secara optimal dalam Implementasi Kebijakan Pemanfaatan Pariwisata TNBKDS.

Kejelasan informasi, Ketersedian SDM dan Tata aliran kerja menjadi masalah pokok. Dalam artian Balai Besar Taman Nasional Betung Kerihun Dan Danau Sentarum (BBTNBKDS) belum menjalankan secara optimal pemanfaatan Pariwista TNBKDS. Hal ini didukung dengan survey dampak sosial ekonomi pariwisata bagi masyarakat desa Sepandan berikut ini.

Survey terkait Dampak Sosal-ekenomi Pariwisata bagimasyarakat desa Sepandan
Sumber: Hasil Penelitian, 2017

Dari data tersebut dapat diketahui bahwa $40 \%$ atau 12 orang dari 30 responden Masyarakat desa Sepandan dalam penelitian ini menyatakan bahwa, pariwisata tidak memberikan dampak sosial ekonomi yang sesuai bagi masyarakat desa Sepandan. Sedangkan hanya $13 \%$ atau 4 orang memberikan jawaban sangat sesuai.

Dengan kata lain hasil survey ini menjadi salah satu indikator bahwa Implementasi Kebijakan Pemanfaatan Pariwisata Taman Nasional Betung Kerihun Dan Danau Sentarum (TNBKDS) dalam pemanfaatan wisata alam di desa

Sepandan belum optimal dalam penyelenggaraanya. Hal ini karena di desa Sepandan belum terbentuk pengelola pariwisata secara mandiri sebagaimana di desa Menua Sadap, selama ini pengelolaan pariwisata di desa Sepandan berada masih sepenuhnya difasilitasi oleh BBTNBKDS.

Belum terbentuknya kelompok pengelola pariwisata di desa Sepandan disebabkan karena belum adanya inisiasi dari kedua belah pihak. Pada dasarnya masyarakat desa Sepandan sangat berharap bahwa BBTNBKDS dapat memanfaatkan pariwisata alam secara optimal. Karena masyarakat desa Sepandan menyadari bahwa jika pariwisata alam TNBKDS jika dimanfaatkan secara optimal akan dapat menjadi roda penggerak perekonomian masyarakat dengan menjadikan pariwisata sebagai mata pencaharian alternatif masyarakat, sebagaimana hasil survey di bawah ini. sebagai Mata PencaharianAlternatif 
Sumber: Hasil Penelitian, 2017

Dari data gambar diagram di atas dapat diketahui bahwa mayoritas responden masyarakat desa Sepandan dalam penelitian ini sebanyak $50 \%$ atau 15 orang responden menyatakan sangat setuju menjadikan pariwisata sebagai mata pencaharian alternatif, 23\% atau 7 orang responden menyatakan setuju menjadikan pariwisata sebagai mata pencaharian alternatif, $13 \%$ atau 4 orang responden menyatakan cukup setuju menjadikan pariwisata sebagai mata pencaharian alternatif dan hanya $7 \%$ atau 4 oarang responden menyatakatan tidak setuju dan sangat tidak setuju menjadikan pariwisata sebagai mata pencaharian alternatif.

Dengan demikian pada dasarnya masyarakat desa Sepandan telah menyadari bahwa pariwisata alam dapat dijadikan sektor andalan dan unggulan yang akan

meninggkatkan taraf kesejahteraan masyarakat desa Sepandan. Dalam laporan tahun desa Sepandan, menyatakan bahwa desa Sepandan mempunyai beberapa potensi unggulan yang bisa dikembangkan yang salah satunya adalah Usaha Agrowisata TNBKDS.

Sementara jika dicermati dari jumlah pengunjung wisatawan pada tahun 2011 sampai tahun 2016 dibandingkan dengan kunjungan pada wisata budaya Menua Sadap, Pengunjung Danau Sentarum melalui desa Sepandan lebih banyak, tercatat pada tahun 2011 sebanyak 142 wisatawan, terjadi penurunan pada tahun 2012 hanya 44 wisatawan.
Pada tahun 2013 terjadi peningkatan yaitu 159 wisatawan, namun terjadi penurunan kembali pada tahun 2014 hanya 79 wisatawan. Kemudian pada tahun 2015 terjadi peningkatan jumlah wisatawan sebanyak 86 wisatawan dan terjadi peningkatan signifikan pada tahun 2016 yaitu sebanyak jumlah pengunjung 153 wisatawan yang berkunjung. Selengkapnya data jumlah pengunjung wisatawan Danau Sentarum pada tahun 2011 sampai 2016 disajikan dalam bentuk tabel di bawah ini.

\section{Data Jumlah Kunjungan Wisatawan Danau Sentarum 2011-2016}

\begin{tabular}{ccc}
\hline No. & Thn. Kunjungan & Jml. Wisatawan \\
\hline 1 & 2011 & 142 Orang \\
2 & 2012 & 44 Orang \\
3 & 2013 & 159 Orang \\
4 & 2014 & 79 Orang \\
5 & 2015 & 86 Orang \\
6 & 2016 & 153 Orang \\
\hline
\end{tabular}

Sumber: SPTN 1 Lanjak

\section{Hambatan dalam Implementasi Kebijakan Pemanfaatan Pariwisata Taman Nasiona Betung Kerihun Dan Danau Sentarum (TNBKDS)}

Dengan mengidentifikasi dan mengamati dari pembahasan di atas, Implementasi Kebijakan Pemanfaatan

Pariwisata Taman Nasional Betung Kerihun Dan Danau Sentarum (TNBKDS) tentunya terdapat beberapa faktor yang menjadi hambatan dalam pengimplementasiannya yang akan berpengaruh pada keberhasilan dalam Implementasi Kebijakan Pemanfaatan Pariwisata TNBKDS.

Adapun berikut di bawah ini adalah hasil identifikasi yang di analisis terkait faktor-faktor yang menjadi hambatan dalam Implementasi Kebijakan 
Pemanfaatan Pariwisata Taman Nasional TNBKDS.

\section{Faktor Komunikasi}

Secara umum pada dasarnya faktor komunikasi yang dilakukan BBTNBKDS sudah cukup baik. Namun hanya baru terfokus pada Implementasi Kebijakan Pemanfaatan Pariwisata Budaya TNBKDS di desa Menua Sadap. Sedangkan Implementasi Kebijakan Pemanfaatan Pariwisata Alam TNBKDS di desa Sepandan dari hasil penelitian berada dalam kategori sedang, dan terkait kejelasan informasi menurut masyarakat desa Sepandan berada dalam kategori buruk, dalam arti masih jauh dari kata maksimal.

\section{Faktor Sumberdaya}

Sumberdaya memang menjadi salah faktor yang dapat mempengaruhi kinerja Implementasi Kebijakan, termasuk dalam Impelementasi Kebijakan Pemanfaatan Pariwisata TNBKDS. Secara umum Implementasi Kebijakan Pemanfaatan Pariwisata TNBKDS dilaksanakan sudah cukup baik. Namun masih terfokus pada Implementasi Kebijakan Pemanfaatan Pariwisata Budaya di desa Menua Sadap.

Sumber: Hasil Penelitian, 2017

Sedangkan dalam Implementasi Kebijakan Pemanfaatan Pariwisata Alam (TNBKDS) di desa Sepandan berada dalam kategori buruk. Terlebih dari segi jumlah pegawai yang kurang memadai terkait pengelolaan pariwisata TNBKDS.

\section{Faktor Struktur Birokrasi}

Faktor yang menjadi penghambat dalam Implementasi Kebijaka Pemanfaatan Pariwisata TNBKDS selanjutnya adalah faktor struktur birokrasi. Sama halnya dengan faktor komunikasi dan sumberdaya, faktor struktur birokrasi pun menurut hasil penelitian ini sudah cukup baik hanya dalam pariwisata budaya di desa Menua Sadap. Adapun di desa Sepandan dalam pemanfaatan pariwisata alam berada dalam ketegori buruk. Buruknya struktur birokrasi dalam pemanfaatan pariwisata alam di desa Sepandan terjadi karena belum terbentuknya kelompok pengelolaan pariwisata secara mandiri yang berbasis masyarakat lokal (community based taourism).

\section{Upaya dalam Mengatasi Hambatan dalam Implementasi Kebijakan Pemanfaatan Pariwisata TNBKDS}

\section{Penyeimbangan}

Komunikasi

Berdasarkan hasil identifikasi dan

pengamatan terkait hambatan - hambatan dari faktor komunikasi, diketahui telah terjadi ketidakseimbangan komunikasi dalam Implementasi Kebijakan Pemanfaatan Pariwisata TNBKDS yang lebih terfokus pada pemanfaatan pariwisata budaya TNBKDS di desa Menua Sadap, dibandingkan dengan pemanfaatan pariwisata alam TNBKDS di desa Sepandan.

Untuk itu, Balai Besar Taman Nasional Betung Kerihun Dan Danau Sentarum (BBTNBKDS) diharapkan dapat berlaku adil dan bijaksana dalam melakukan komunikasi eksternal terkait pemanfaatan pariwisata alam TNBKDS di desa Sepandan melalui sosialisasi intensif tingkat desa, pelatihan kepariwisataan bagi masyarakat desa Sepandan dan meningkatkan intensitas komunikasi melalui media (elektronik dan surat kabar) serta maksimalkan peran mitra yang bergerak dikepariwisataan seperti Komunitas Pariwisata Kapuas Hulu (KOMPAKH) dan World Wide Fund.

\section{Memaksimalkan Sumberdaya}

Pokok permasalahan terkait faktor penghambat dari Sumberdaya ialah kurangnya sumberdaya manusia secara jumlah yang memadai dalam Implementasi Kebijakan Pemanfaatan Pariwisata TNBKDS, terkhusus dalam pariwisata alam di desa Sepandan. Selama ini dalam pengimplementasian 
tersebut dibebankan pada Seksi bidang Pelayanan dan Pemanfaatan (P2) BBTNBKDS yang berjumlah 4 (empat) orang pegawai dengan wilayah kerja zona pemanfaatan TNBKDS seluas 25.838,54 hektar.

Untuk itu, upaya lakukan guna mengatasi hambatan dalam dimensi sumberdaya dapat dilakukan pengadaan/ pembukaan pegawai baru berdasarkan kompetensi pada bidang kepariwisataan atau mengadakan pelatihan dan pendampingan kepada masyarakat lokal secara intensif dan dapat memaksimalkan peran mitra yang bergerak pada bidang kepariwisataan dan pemberdayaan masyarakat lokal seperti Komunitas Pariwisata Kapuas Hulu (KOMPAKH), World Wide Fund (WWF), Riak Bumi, Dian Tama, AMAN, Canopy, Asppuk, Forclime dan Asian Development Bank (ADB) Hearth of Borneo (HoB).

\section{Penyederhanaan Struktur Birokrasi}

Upaya ini dapat dilakukan oleh BBTNBKDS dengan membentuk Kelompok Pengelola Pariwisata (KPP) berbasis masyarakat (community based tourism) secara mandiri di Kawasan Pemanfaatan Pariwisata TNBKDS sama halnya seperti di desa Menau Sadap. Pembentukan Kelompok ini dapat diinisiasi oleh BBTNBKDS bersama Pemerintahan desa setempat dan pendampingan oleh mitra seperti Kompakh dan WWF.

\section{KESIMPULAN DAN IMPLIKASI}

penelitian ini dapat disimpulkan:

1) Bahwasannya dalam Implementasi Kebijakan Pemanfaatan Pariwisata TNBKDS terbagi dalam 2 (dua) klasifikasi berdasarkan objek daya tarik wisata (ODTW) yaitu wisata budaya, salah satunya budaya Dayak Iban Menua Sadap dan Wisata alam Danau Sentarum. Yang secara umum perspektif implementor diperoleh skor penilaian 3,33 yang menurut kriteria penafsiran termasuk dalam kategori sedang.

2) Secara spesifikasi objek daya terik wisata (ODTW) budaya, kinerja implementor dalam implementasi kebijakan pariwisata budaya TNBKDS di desa Menua Sadap diperoleh skor penilaian 3,49 yang menurut kriteria penafsiran termasuk dalam kategori baik.

3) Adapun dalam spesifikasi objek daya tarik wisata (ODTW) alam, kinerja implementor dalam Implementasi Kebijakan Pemanfaatan Pariwisata Alam (TNBKDS) di desa Sepandan diperoleh skor penilaian 2,60 yang menurut kriteria penafsiran termasuk dalam kategori buruk.

2) Perbedaan hasil kinerja implementor

dalam Implementasi Kebijakan Pemanfaatan Pariwisata TNBKDS, antara pariwisata budaya Dayak Iban Menua Sadap dan Pariwisata Alam Danau Sentarum di desa Sepandan diketahui dalam penelitian ini karena adanya perbedaan pada faktor kultur/budaya (budaya tradisional dayak Iban dan budaya modern melayu) yang mempengaruhi kinerja pelaksana kebijakan (implementor) dalam Implementasi Kebijakan Pemanfaatan Pariwisata TNBKDS.

3) Dalam kaitan pemahaman/pandangan tentang pariwisata, baik masyarakat desa Menua Sadap maupun masyarakat desa Sepandan. Sebagai sasaran kebijakan sepakat bahwasannya pariwisata jika dikelola dengan baik akan dapat menjadi roda penggerak perekonomian masyarakat, yang akan membuka kesempatan/peluang berusaha dan bekerja masyarakat, sehingga hal itu dapat meningkatkan kesejahteraan masyarakat.

\section{Implikasi}

Dalam penelitian ini implikasi yang berkembang meliputi 2 (dua) hal yaitu, 
pertama implikasi teoritis; yang berkaitan dengan kontribusi terhadap perkembangan teori-teori Implementasi kebijakan dalam pemanfaatan pariwisata kawasan Taman Nasional. Dan kedua implikasi praktis yang berkaitan dengan kontribusi penelitian ini terhadap Implementasi Kebijakan Pemanfaatan Pariwisata Taman Nasional betung Kerihun Dan Danau Sentarum (TNBKDS) di Kabupaten Kapuas Hulu propinsi Kalimantan Barat. Dan berikut di bawah ini penjelasan lebih lanjut terkait implikasi yang berkembang dalam penelitian ini.

\section{Implikasi Teoritis}

Penelitian ini menggunakan model teori implementasi kebijakan G. Edward yang didasari pula oleh berbagai teori, salah satunya adalah teori Van Mater dan Van Horn. Pendekatan model teoritis G. Edward III mengajukan 4 (empat) variabel yang berperan penting dalam pencapaian keberhasilan implementasi, seperti; (1) komunikasi; (2) sumberdaya; (3) disposisi dan (4) struktur birokrasi. Sebagaiman dalam gambar berikit ini.

\section{Kerangka Model Implementasi Edward III}

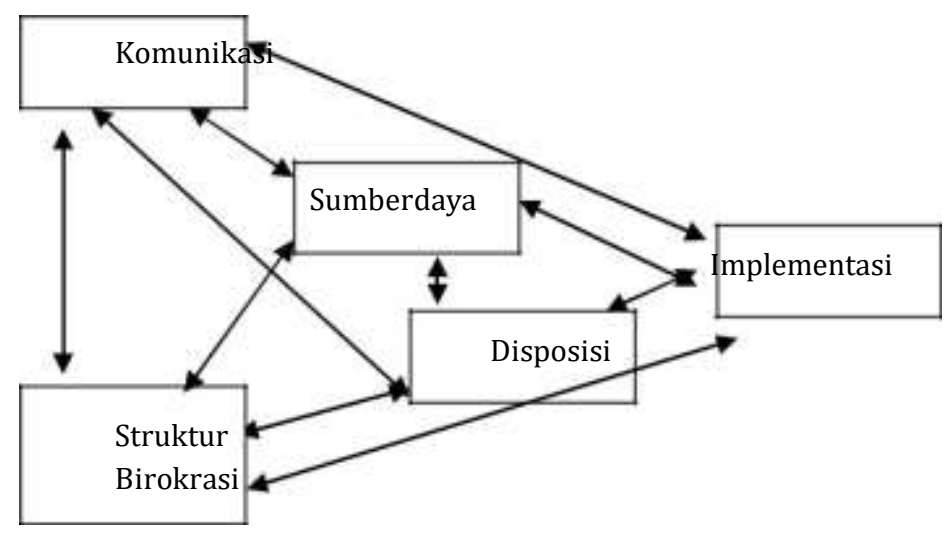

Sumber: Widodo, 2011

\section{Implikasi Praktis}

Dari hasil penelitian ini diharapkan dapat memberikan kontribusi yang berimplikasi pada kebijakan pemanfaatan pariwisata TNBKDS, seperti :

1) Pemanfatan Pariwisata Taman Nasional Betung Kerihun Dan Danau Sentarum (TNBKSD) seyogyanya penyampain informasi dilakukan dengan intensitas yang rutin melalui jaringan komunikasi media social yang saat ini digemari masyrakat.

2) Disamping itu, koordinasi lintas sektoral dengan dinas terkait seperti dinas pariwisata tentunya harus dilakukan secara intensif. Dimana dalam temuan lapangan, berdasarkan wawancara dengan responden nomor 1 (satu) dari dinas pariwisata diketahui bahwa proses koordinasi baru sampai pada tahap perencanaan. Sementara koordinasi pada tahap implementasi dan pengawasan masih berjalan sendirisendiri antara dinas pariwisata dengan Balai Besar TNBKDS.

3) Seyogyanya pihak BBTNBKDS melakukan penambahan jumlah pegawai yang memiliki kompetensi dibidang kepariwisataan, sehingga pemanfaatan pariwisata TNBKDS dapat berjalan dengan optimal. Karena berdasarkan pengamatan langsung dilapangan, peneliti tidak menemukan adanya pegawai yang memiliki latar belakang dari kepariwisataan. Dan tidak adanya bidang/subbidang yang bergerak secara khusus dan terfokus pada pemanfaatan pariwisata TNBKDS. Sehingga dengan hal itu diharapkan tidak ada tumpang tindih dalam pengelolaan pariwisata TNBKDS.

4) Diharapkan implementor tetap menjalin hubungan yang baik dengan sasaran kebijakan seperti selalu melakukan pendampingan kepada sasaran kebijakan. Hal ini penting dilakukan agar tidak adanya prasangka atau curiga dari masyarakat lokal. Seperti halnya dalam penemuan lapangan di desa 
Sepandan, menurut responden nomor 1(satu), pihak BBTNBKDS dianggap tidak terbuka terkait wisatawan yang datang ke kawasan pemanfaatan pariwisata alam TNBKDS. Hal itu terjadi karena di desa Sepandan belum terbentuk pengelola pariwisata berbasis masyarakat (Community based tourism).

\section{DAFTAR PUSTAKA}

Anonim. 2016. Laporan Kinerja BBTNBKDS 2016. Kapuas Hulu: UPT BBTNBKDS

Anonim. 2016. Laporan Tahunan Desa Sepandan 2016. Kapuas Hulu: Desa Sepandan

Anonim. 2016. Laporan Tahunan Desa Sadap 2016. Kapuas Hulu: Desa Sepandan

Anonim. 2017. Rekapitulasi jumlah kunjungan wisatawan desa wisata Sadap 2011-2016. Kapuas Hulu: Komunitas Pariwisata Kapuas Hulu (Kompakh)

Anonim. 2017. Rekapitulasi jumlah kunjungan wisatawan Danau Sentarum 2011-2016. Kapuas Hulu: SPTN 1 Lanjak 